\title{
COMPOSITIONS OF SOLID WASTES GENERATED FROM A SCHOOL CAMPUS
}

\author{
Renato Ortiz Arazo 1

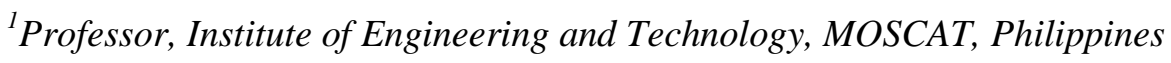

\begin{abstract}
Efficient handling of solid wastes starts in determining its compositions and generation rate. A study was carried out to examine the compositions of solid wastes generated in a school campus from four major sources: (1) classrooms and offices, (2) food services, (3) hallways and outdoors, and (4) residence halls and cottages. Waste stream from each source was segregated according to: paper and paper products, hard plastics, soft plastics, glasses, metals, woods, food leftovers, yard, textile, inorganic, hazardous, and special wastes. Result showed variation of weight percentages of wastes from four sources: cottages and residence hall (37\%), hallways and outdoors (30\%), classrooms and offices (21\%) and food services (12\%).Compositional analyses revealed that $48.34 \mathrm{wt} \%$ of the waste stream from the campus are organic / compostable (food, yard, and wood). The $29.72 \mathrm{wt} \%$ are recyclables (paper, hard plastics, glass, metal) while the residuals constituted the remaining 21.94 wt\% (special, hazardous, textile, soft plastics, inorganic). The highest generation rate is in the residence hall and cottages with $0.56 \mathrm{~kg} / \mathrm{capita-}$ week.
\end{abstract}

Keywords: Waste characterization, solid waste audit, waste generation rate, school waste composition

\section{INTRODUCTION}

Availability of reliable waste management data is a valuable resource in pursuing a comprehensive, critical and informative evaluation of waste management options in all waste management programs $[1,2]$. With available data, the greatest challenge of coming up a comprehensive solid waste management (SWM) programs will be given direction and will help in achieving institutional sustainability [3]. This requires thorough understanding of the different compositions of waste in the stream. School campus, for instance, can better carryout waste handling, treatment and disposal when its compositions and generation rate are available.

Knowledge of the compositions of waste stream in the campus provides many advantages. Efficient dustbin for each waste kind such as biodegradable, non-biodegradable, and recyclables can be provided to cater the expected volume of wastes in between collection period. Volume can also be the determinant in knowing the frequency or interval of collection especially when each kind of waste is collected in separate schedules. The development of Material Recovery Facility (MRF) to keep recyclables is dependent to the volume of different recyclable materials that can be taken from the waste stream. Besides, the capacity of waste collection truck is dependent to the volume of wastes generation it serves. Disposal site selection and development are likewise dependent on the kind and volume of wastes it caters [4].

It is, however, noticed that some, if not many, academic institutions take for granted waste characterization study in their respective campuses. Though some have in-placed solid waste management, there is limited study as to whether the dustbins they provided can accommodate the volume of wastes generated in area where it serves.

A waste characterization study was carried out in a stateowned college in the Philippines - the Misamis Oriental State College of Agriculture and Technology (MOSCAT). It aimed to determine the compositions of wastes generated from the different sources of the campus. Generation rate was also determined which serves as basis in providing efficient dustbins in different areas of the campus. It is hope that this study would become guide and inspiration for other school campuses to carry out solid waste characterization.

\section{MATERIALS AND METHODS}

\subsection{Research Setting}

A state-owned tertiary school of the Philippines, Misamis Oriental State College of Agriculture and Technology (MOSCAT), was the location of the study. Particularly, this is situated in the farming community of Claveria, Misamis Oriental- the southern part of the Philippines. It is approximately 603 meters above mean sea level.

\subsection{Solid Wastes Sources}

Waste sources were classified into four (4) which are specifically describe below:

a) Classrooms and offices -include classrooms, offices, laboratories, libraries and other special use facilities (museum, infirmary and auditorium/gym).

b) Food services -include the cafeteria, canteen, and hostel.

c) Hallways and outdoors -include buildings corridors, walkways and streets inside the school premises. 
d) Residence halls and cottages -include student residence halls and the faculty and staff cottages inside the campus.

\subsection{Data Gathering Procedures}

Data were gathered during the four (4) weeks sampling period. All wastes from different sources were considered in the study. Averages were used in making graphs and tables.

Waste stream compositions were tabulated according to the following classifications: food wastes, glasses, metals, papers and paper products, plastics, yard wastes, hazardous, textiles, woods, special, and other inorganic.

Solid waste from each source was labeled properly during collection. The total waste stream from each source was sorted accordingly. Percent mass composition of each waste classification was determined using Eq 1.

$w t \%$ of mat $^{\prime} l=\frac{\text { mass of material }}{\text { total mass of waste stream }} \times 100$

GenRate by capita $=\frac{\text { mass of wastes }}{\# \text { of wastes generators }}$

The number of waste generators from each source was counted in every sampling week. This included the total number of students in the campus, the residents of the faculty and staff cottages whose wastes were included in the waste stream, the residents in student dormitories/residence halls, and the members of the faculty and staff of the school.

Though waste generators did not stay for 24 hours in the generation site, it is important to include all of them to quantify how much waste generated when they were on-site. Generation rate could estimate the needed dustbin to accommodate the wastes generated in a particular source. The weekly per capita generation rate (kg/capita-week) was computed using Eq 2.

\section{RESULTS AND DISCUSSION}

\subsection{Solid Waste Generation Rate}

Highest per capita generation rate was found in residence halls and personnel cottages with $0.562 \mathrm{~kg} /$ capita-week while the lowest rate was from food services with 0.024 $\mathrm{kg}$ /capita-week (Table 1).

Result of the study revealed that the generation rate of solid waste in residence hall and cottages is within the average weekly household per capita generation of $0.171-29.03 \mathrm{~kg}$ [5]. However, generation rates of other sources were found extremely below the reported average generation rate.
Table-1. Per capita generation rate of solid wastes from different sources

\begin{tabular}{lc}
\hline Waste Source & $\begin{array}{c}\text { Per Capita Generation Rate } \\
(\mathrm{kg} / \text { capita-week })\end{array}$ \\
\hline $\begin{array}{l}\text { Residence halls and faculty } \\
\& \text { staff cottages }\end{array}$ & 0.562 \\
Hallways and outdoors & 0.044 \\
Classrooms and offices & 0.031 \\
Food services & 0.024 \\
\hline
\end{tabular}

Wastes from food services were found to have the least generation rate $(0.024 \mathrm{~kg} /$ capita-week). Generally, food leftovers from these sources were used as feeds for animals. Moreover, serving of meals and snacks did not use disposable utensils.

Results of the study imply effective "reduction at source" strategy of the school to minimize waste stream that reached the Eco-Park, a place where wastes were segregated and processed. Waste generators effectively carried out the school's campaign of 3R's "Reduce, Reuse, and Recycle" as mandated by Republic Act 9003 otherwise known as Philippines Solid Waste Management Act of 2000.

\subsection{Composition of Wastes from Different Sources}

\subsubsection{Wastes from Classrooms and Offices}

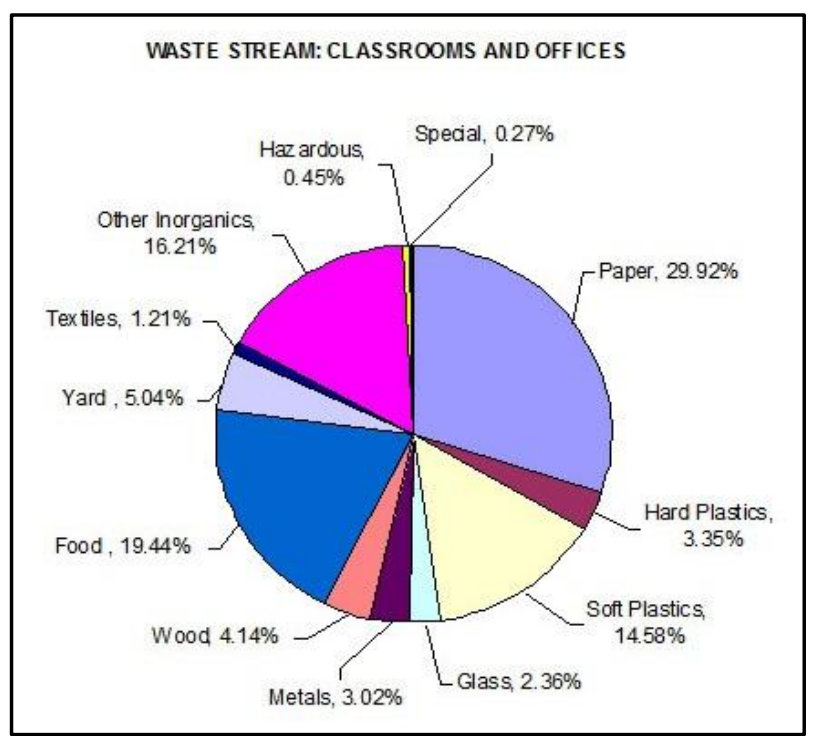

Figure-1. Distribution of wastes compositions from classrooms and offices (wet weight)

Paper and paper products (29.92 wt\%) got the highest percent composition of the waste stream from classrooms and offices (Fig.1). This dominated the waste stream from this source considering that students and school personnel spent most of their office hours in these areas.

Significant mass of food wastes (19.44 wt\%), plastics (17.93 $\mathrm{wt} \%-14.58 \%$ soft plastics and $3.35 \%$ hard plastics) and other inorganic $(16.21 \mathrm{wt} \%)$ constituted the remaining 
components. Food wastes from the classrooms and offices imply that personnel and students alike brought foods inside offices and classrooms. In addition, the considerable percentage of plastics constitutes food wrappers and beverage bottles.

\subsubsection{Wastes from Food Services}

Figure 2 shows the three largest compositions of waste stream, in weight percentages, from food services which were food wastes (56.16), soft plastics (13.67) and papers (10.16). Weight percentages of special, hazardous and wood wastes were minimal with $0.64,0.32$ and 0.05 , respectively. No textile products found in the waste stream from the food services.

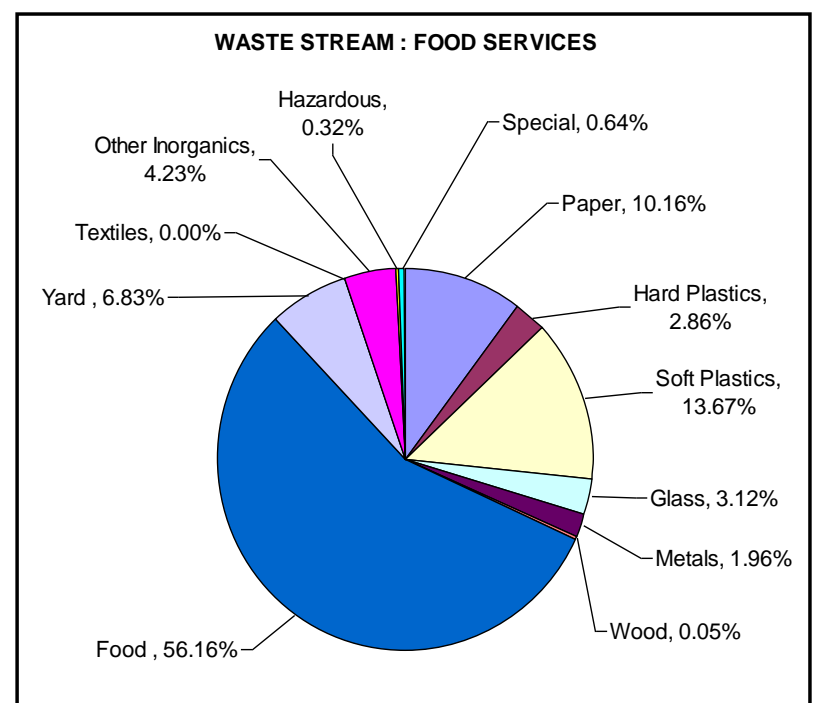

Figure-2. Distribution of wastes compositions from food services (wet weight)

The main composition from food services was kitchen wastes because of fruit and vegetable peelings, and other refuse in meals and snacks preparations. Soft plastics such as cellophanes were used as wrappers of some snacks. Minimal amount of hard plastics $(2.86 \mathrm{wt} \%)$ was the result of the minimal use of disposable utensils and non availability of PET/bottled soft drinks. Considerable amount of papers $(10.16 \mathrm{wt} \%)$ found in the waste stream was derived from paper packaging materials and scratch papers of students who stayed in these areas while doing their academic works.

This result is supported by the waste characterization study of the University of Washington [6] whereby the three largest waste components found in food services were papers $(40 \%)$, food wastes $(38 \%)$ and plastics $(15 \%)$. Red River College in Canada [7] further strengthened the result of this study stipulating that the major components of wastes generated from food services include food wastes $(63.30 \%)$, papers $(16.50 \%)$ and plastics $(12 \%)$.

\subsubsection{Wastes from Residence Halls \& Cottages}

Paper and paper products $(37.02 \mathrm{wt} \%)$ were dominant in the waste stream from residence halls (dormitories) and cottages
(Fig. 3). This was closely followed by food wastes (27.03 $\mathrm{wt} \%)$ and plastics (14.07 wt $\%-11.80 \mathrm{wt} \%$ soft plastics and $2.27 \mathrm{wt} \%$ hard plastics). Inorganic constituted $9.86 \mathrm{wt} \%$ while special wastes got $2.63 \mathrm{wt} \%$. Minimal weight percentages include yard, textiles and hazardous wastes with $1.02,0.74$ and 0.40 , respectively.

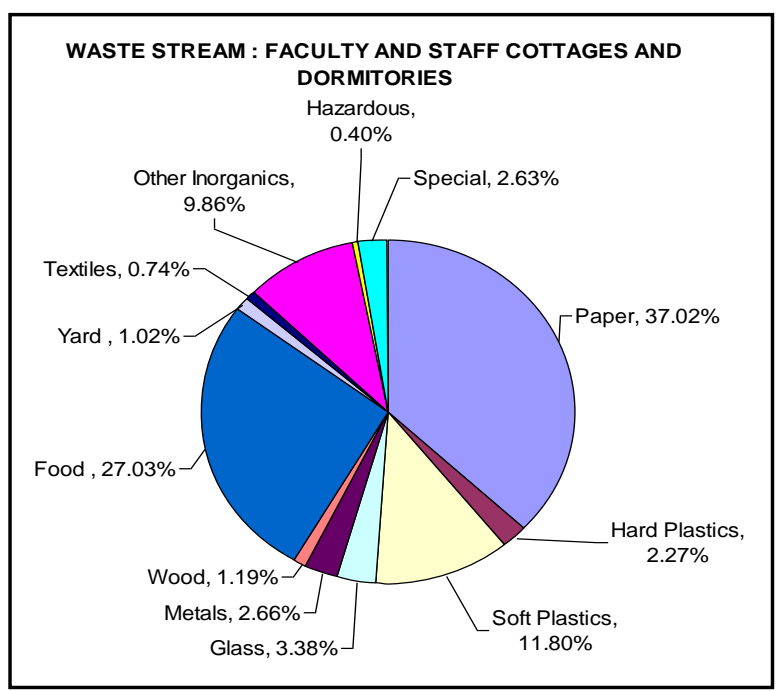

Figure-3. Distribution of wastes compositions from cottages and residence halls (wet weight)

Finding of previous study [6] supported the result of this work stressing that the top three components of the solid wastes generated from residence halls include papers, organics and plastics.

\subsubsection{Wastes from Hallways and Outdoors}

Waste stream from hallways and outdoors largely composed of yard wastes constituting $65.50 \mathrm{wt} \%$ (Fig 4). Yard wastes included yard trimmings and falling leaves. Yard waste was distantly followed by food wastes $(13.37 \mathrm{wt} \%)$, soft plastics $(6.27 \mathrm{wt} \%)$ and papers $(5.72 \%)$. Minimal weight percentages were recorded in special wastes, glasses and hazardous materials with $0.22,0.04$ and 0.02 , respectively.

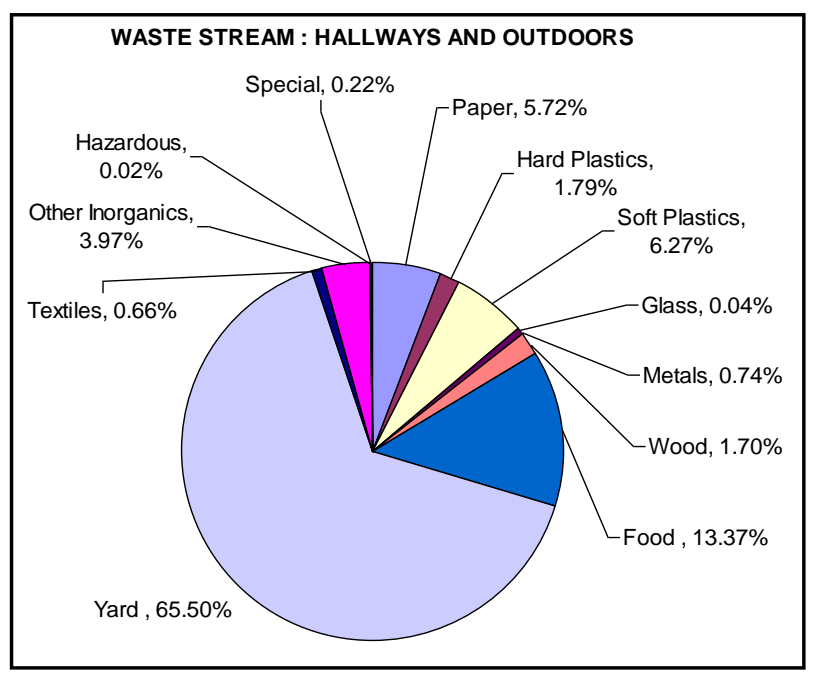

Figure-4. Distribution of wastes compositions from hallways and outdoors (wet weight) 


\subsection{Compositions of Campus-wide Wastes}

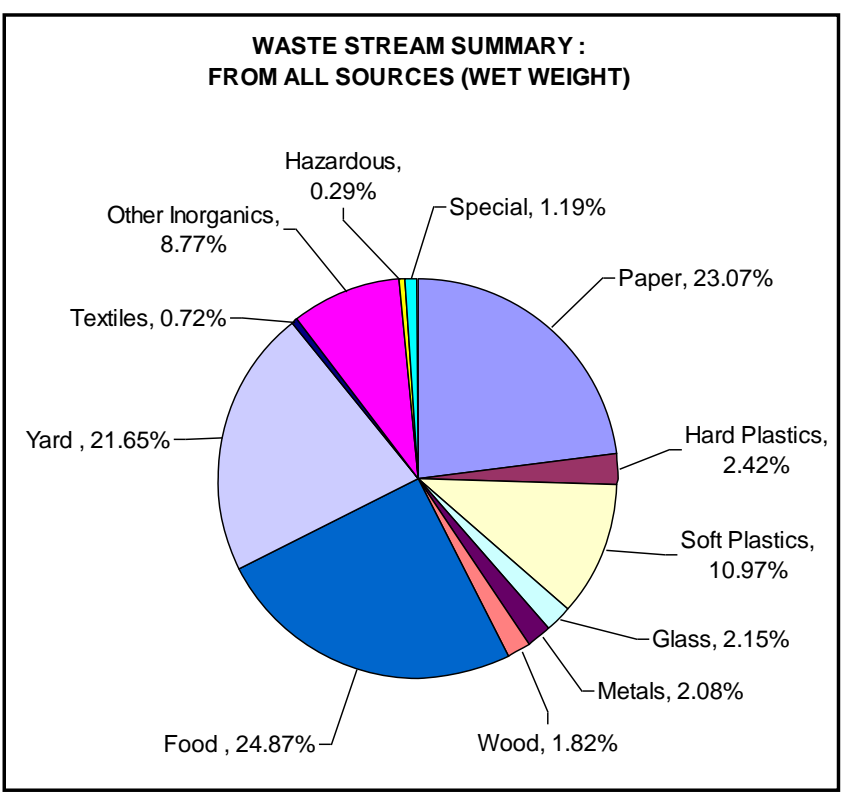

Figure-5. Distribution of wastes compositions from all sources (wet weight)

As revealed in Figure 5, the four highest components, in weight percentages, of the waste stream in the campus were food wastes (24.87), papers (23.07), yard wastes (21.65), and soft plastics/cellophane (10.97). The components of special, textiles and hazardous wastes were minimal with weight percentages of $1.19,0.72$ and 0.29 , respectively.

Yard and food wastes are organics which could be utilized in making organic compost. This implies that school campus can generate compost that can be used as fertilizers in the landscape. Glasses, metals, papers, and plastics are recyclables that can be kept in the MRF for possible recycling or sales to junk buyers.

\subsection{Percentage of Wastes from Four Sources}

Faculty and staff cottages including the students' residence halls generated the highest wastes weight percentage of 37 . This was closely followed by wastes generated from hallways and outdoors (30 wt \%). The remaining weight percentage is shared by wastes generated from classrooms and offices (21 wt \%), and food services (12\%).

High volume of wastes generated from residence hall and cottages was mainly because of the fact that this source generated wastes round-the-clock. This is in contrary to other wastes sources in which the generation eight (8) hours per day only from Monday until Friday per week.

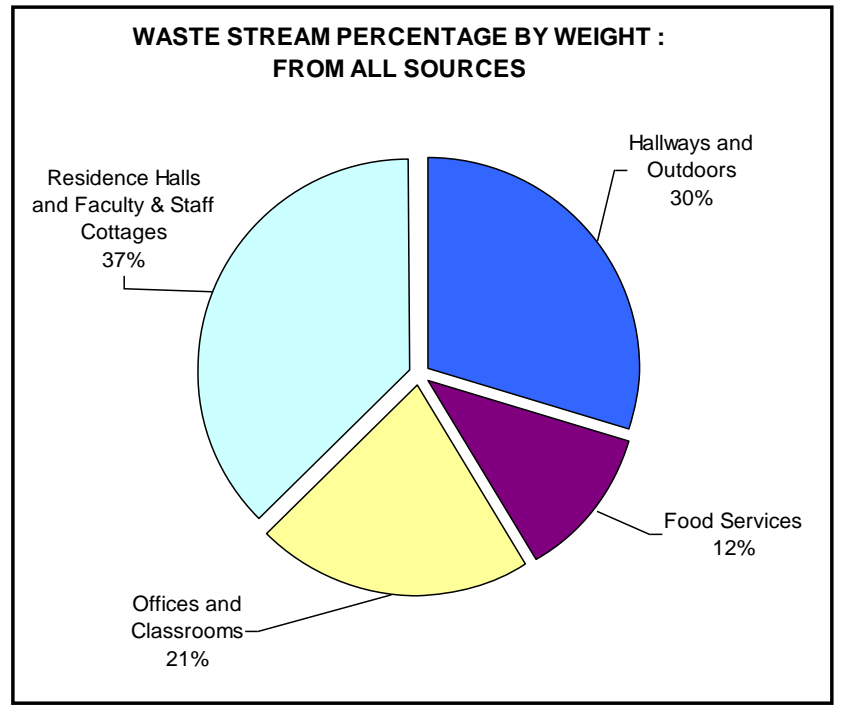

Figure-6. Distribution of waste stream from four sources

\section{CONCLUSIONS}

Based on the solid wastes characterization of the school campus, the following conclusions were drawn:

1. Compared to household, the waste generation rate in school campus is generally low.

2. Major component of the waste stream from the school campus are organics which can be used as source of compost to fertilize school's landscape.

3. Campus waste stream consists of many recyclables which can either be sold to junk buyers for additional income or be utilized for making new (recyclable) product like engineering material.

4. High percentage of wastes is derived from residence halls and cottages, and in outdoors and hallways.

5. Different sources of waste have different components implying that each of this shall be dealt with accordingly in terms of frequency of collection, dust bins volume, and schedule of collection.

\section{ACKNOWLEDGMENT}

The author would like to acknowledge the financial support of the Faculty Development Program of the Philippine Commission on Higher Education (CHED) and the technical help of Engr.Ma. Isabel Dumlao.

\section{REFERENCES}

[1] Miezah K, Obiri-Danso K, Kádár Z, Fei-Baffoe B, Mensah MY. Municipal solid waste characterization and quantification as a measure towards effective waste management in Ghana. Waste Manag 2015. doi:10.1016/j.wasman.2015.09.009.

[2] Baldwin E, Dripps W. Spatial characterization and analysis of the campus residential waste stream at a small private Liberal Arts Institution. Resour Conserv Recycl 2012;65:107-15. doi:10.1016/j.resconrec.2012.06.002.

[3] Smyth DP, Fredeen AL, Booth AL. Reducing solid waste in higher education: The first step towards 
"greening" a university campus. Resour Conserv

Recycl 2010;54:1007-16.

doi:10.1016/j.resconrec.2010.02.008.

[4] Boysan F, Özer Ç, Has M, Murat M. Project on Solid Waste Recycling Plant in Sakarya University Campus. Procedia Earth Planet Sci 2015;15:590-5. doi:10.1016/j.proeps.2015.08.108.

[5] Suthar S, Singh P. Household solid waste generation and composition in different family size and socioeconomic groups: A case study. Sustain Cities Soc 2015;14:56-63. doi:10.1016/j.scs.2014.07.004.

[6] University of Washington. University of Washington waste characterization study 2004. https:/www.washington.edu/facilities/building/recycli ngandsolidwaste/files/archives/UW_Waste_Characteri zation_Study_2004.pdf (accessed October 16, 2015).

[7] Campbell M, Costello T, Davies C, Dobrev R, Frezghi A, Kozak C, et al. Solid waste audit report of Red River College 2011. http://www.rrc.mb.ca/files/File/environmentalmanag/S olidWasteAudit1.pdf (accessed October 16, 2015).

\section{BIOGRAPHY}

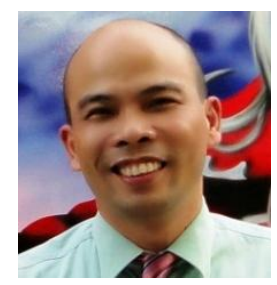

Dr. Renato Arazo is currently the Dean of Institute of Engineering and Technology of MOSCAT. He was a visiting scholar in Texas A\&M University, Texas, USA 